\title{
Analysis of Student Misconceptions on the Problem Based Learning (PBL) Model Assisted with Interactive Multimedia on Acid Basic Solutions
}

\section{Fitriani Mandasari \& *Irwan Said}

Program Studi Pendidikan Kimia/FKIP - Universitas Tadulako, Palu - Indonesia 94119

Received 25 June 2021, Revised 26 July 2021, Accepted 20 August 2021

doi: 10.22487/j24775185.2021.v10.i3.pp195-202

\begin{abstract}
This study aimed to analyze students' misconceptions on acid-base solution after applying the problem based learning (PBL) model assisted with interactive multimedia in grade XI at SMA 4 Palu. This type of research was a quantitative descriptive study with a total sample of 1 class, namely class XI Science-2, with 33 students. The research instrument used was a reasoned multiple-choice test accompanied by a Certainty of Response Index (CRI) consisting of 15 items. The results obtained the average percentage of students' misconceptions in Problem Based Learning (PBL) assisted with interactive multimedia in Acid-Base Solutions before and after the successive application was $42.9 \%$ and $21.8 \%$. Therefore, the application of the PBL model reduced student misconceptions by $21.1 \%$.
\end{abstract}

Keywords: Analysis, misconception, problem-based learning, interactive multimedia, acid-basic solutions

\section{Introduction}

Education plays an essential role in human life. Along with the development of technology and the times, education has also developed. To achieve a quality level of education, a learning system is needed that creates students' potential and human resources who master science (Desnylasari, 2016).

Increasingly modern developments, especially in the era of globalization as it is today, demand fundamental changes in various fields, including education, 1998 UNESCO has proposed four pillars of learning, namely learning to know (learning to understand), learning to do (learning to do), learning to live. In togetherness (learning to live together) and learning to be yourself (learning to be). Chemistry is a branch of science that underlies the development of technology and the concept of living in harmony with nature. So that it makes a significant contribution to human life, chemistry is studied at the level of secondary school education to college (Medina, 2017).

Chemistry is a subject with a lot of abstract material (Gabel, 1999). Certain concepts cannot be explained without using analogies or models, so that high reasoning power is needed in studying chemistry (Yunitasari et al., 2013).

The right strategy to reduce and eliminate students' misconceptions as early as possible needs to be done. Students already have an initial concept or preconception about an event before taking formal lessons under the teacher's guidance. After getting new knowledge, students will align their initial expertise with new knowledge obtained from traditional learning. Students can build their knowledge in this alignment process, but some experience misconceptions (Yunitasari et al., 2013).

Concepts are composed of interrelated simple declarative statements (propositions) that describe students' building of knowledge about a concept. Students' understanding of concepts not by scientific conceptions or what is generally accepted is categorized as misconceptions. Several misconceptions in chemistry have been investigated in previous studies. These misconceptions occur typically because of the abstract nature of the concepts given by the teacher so that the concepts previously received by students experience misunderstandings (Afadil \& Diah, 2018).

Chemical misconceptions experienced by students are very detrimental to fluency and success, mainly if the misunderstandings have occurred for a long time and are not detected early, both by the students themselves and the teacher (Astuti et al., 2016). Misconceptions are very disturbing for the development of science, especially knowledge whose application involves various aspects of life such as chemistry. Therefore, teachers must analyze the misconceptions experienced by students and try to overcome them through classroom learning. This is important because misconceptions also impact students' understanding of the lesson so that

*Correspondence:

Irwan Said

e-mail: puangatto@yahoo.com

(c) 2021 the Author(s) retain the copyright of this article. This article is published under the terms of the Creative Commons Attribution-NonCommercial-ShareAlike 4.0 International, which permits unrestricted non-commercial use, distribution, and reproduction in any medium, provided the original work is properly cited. 
learning outcomes are low (Medina, 2017). The fact is that students still have misconceptions even though the learning process has used inquiry (Hastuti et al., 2014).

The way to realize the success of learning activities is to choose a suitable learning model. One of the models expected to improve the quality of learning is applying the problem-based learning (PBL) model. The PBL model has several advantages, including problem-solving provided can challenge and awaken students' critical thinking skills and give satisfaction to discover new knowledge; learning with the PBL model can increase student activity in the learning process and can provide opportunities for students to apply the knowledge they have into the real world (Rosidah et al., 2014)

This model is very different from the conventional teacher-centered learning model. A drastic change from traditional learning to a full PBL model can be difficult. This is mainly in the mindset and independence of students. They combine this model with other methods (Nurhayati et al., 2013).

One of the efforts made in this study, the PBL model, was modified with interactive multimedia. Amrulloh et al. (2013) stated that receiving lesson information would be better if interactive media supported it. Devi et al. (2014) said that with the development of information technology, the world of education is always moving forward dynamically, especially in creating or creating educational media, methods, and materials to be more interesting. The advantage of using interactive multimedia is that it can present abstract objects in concrete and provide direct experience to students because they can interact with the concepts they are learning. Compared to other media, interactive multimedia is easier to use and contains moving images to facilitate understanding of a concept. The results of Yang et al. (2004) show that the use of interactive multimedia can reduce students' misconceptions about the subject matter of electrochemistry because computer animation in the form of graphics and chemical reactions contained in interactive multimedia can help students understand the material and change the misconceptions they previously experienced into correct conception.

This paper is intended to present a description of students' misconceptions in Interactive Multimedia Assisted Problem Based Learning (PBL) on Acid-Base Solutions in Class XI SMA Negeri 4 Palu.

\section{Methods}

This research is quantitative descriptive research that uses a measurement technique in a test accompanied by a Certainty of Response Index (CRI). The research design used is one group pretest-posttest design (Sugiyono, 2015), in Table 1 .
Table 1. Research design one group pretestposttest design

\begin{tabular}{cccc}
\hline Group & Pretest & Perlakuan & Postest \\
\hline Eksperimen & $\mathrm{O}_{1}$ & $\mathrm{X}$ & $\mathrm{O}_{2}$ \\
\hline
\end{tabular}

Description:

$\mathrm{O}_{1} \quad=$ pretest;

$\mathrm{X}=$ problem-based learning with interactive multimedia-assisted learning;

$\mathrm{O}_{2}=$ posttest.

This research was conducted at SMA Negeri 4 Palu, and the time of the study was carried out from January 8 to 17,2019 . The population in this study were all XI grade students of SMAN 4 Palu in the 2018/2019 academic year. The sample of this study were students of class XI IPA $2(n=33)$.

The sampling technique is purposive sampling, which is one of the non-random sampling techniques where the researcher determines the sample by determining unique characteristics by the research objectives and the teacher's considerations. The research instruments used in this study were learning tools consisting of lesson plans and LKPD, learning observation sheets for teachers and students, and a misconception tracking test in the form of multiple-choice reasoned accompanied by CRI (Certainty of Response Index). This CRI method is one way to identify misconceptions and distinguish them from not knowing the concept and knowing the idea (Hasan et al., 1999).

This test was given two times, namely at pretest and posttest. The misconception tracking test used is a multiple-choice test that previously went through the experts' validation stage. To determine which concepts are best understood by misconceptions by respondents, it can be done by identifying misconceptions in groups. The identification of misconceptions in groups is based on the average CRI index of respondents who answered correctly (CRIB) and the average CRI index of respondents who responded incorrectly (CRIS), and the fraction of respondents who answered correctly (Fb) (Nuha \& Sukarmin, 2013).

Teacher and student activities are activities or behaviors carried out in the interaction process (teachers and students) to achieve learning objectives in the teaching and learning process (Depdiknas, 2005).

Observations of students showed that students were less active in participating in lessons, especially chemistry learning on acid-base solution material, the level of understanding of students was still low, this was seen in the results of daily tests of students who had a low completeness score of $30.4 \%$, and incompleteness scores. which is $69.6 \%$ high 


\section{Results and Discussion}

The learning process was carried out for three meetings and was added to two pretest and post-test sessions. The learning process is observed by observers who will give values through the observation sheets that have been provided, where the results obtained are to see the implementation of learning tools, namely RPP and LKPD.

Table 2. The results of the assessment of the implementation of learning by teachers

\begin{tabular}{cc}
\hline \multirow{2}{*}{ Meeting } & Percentage (\%) \\
\cline { 2 - 2 } & Experiment Class \\
\hline Meeting 1 & 83.3 \\
Meeting 2 & 88.8 \\
Meeting 3 & 91.6 \\
\hline Average & 87.9 \\
\hline
\end{tabular}

Based on Table 2, an assessment of the implementation of learning by the teacher can be obtained by applying the PBL model assisted by interactive multimedia that every meeting there is an increase.

Meetings 1, 2 and 3 respectively obtained values of $83.3 \%, 88.8 \%$, and $91.6 \%$. From the value obtained, there was an increase of $5.5 \%$ from meeting 1 to meeting 2 and $2.8 \%$ from meeting 2 to meeting 3. This happened because the main factor was that the teacher continued to conduct self-evaluations related to the results of the assessment of the implementation of learning at the meeting. Previously, as in the core stage of the Student Orientation on Problems, at this point, the teacher did not provide questions in the form of problems related to real-life so that at the next meeting, it became the teacher's consideration to be aware of the shortcomings that had been made in the learning process, and in the end obtained the increase for each meeting reached a value of $87.9 \%$ which was included in the perfect criteria $(75 \%$ Value 100\%) (Depdiknas, 2005).

Based on Table 3, an assessment of the implementation of learning by teachers can be obtained by applying the PBL model assisted by interactive multimedia that every meeting there is an increase.
Table 3. The results of the assessment of the implementation of learning by students

\begin{tabular}{cc}
\hline \multirow{2}{*}{ Meeting } & Percentage (\%) \\
\cline { 2 - 2 } & Experiment Class \\
\hline Meeting 1 & 82.7 \\
Meeting 2 & 84.4 \\
Meeting 3 & 88.7 \\
\hline Average & 85.2 \\
\hline
\end{tabular}

Meetings 1, 2 and 3 respectively scored $82.7 \%, 84.4 \%$, and $88.7 \%$. From the value obtained, there is an increase of $1.7 \%$ from meeting 1 to meeting 2 and $4.3 \%$ from meeting 2 to meeting 3. This happens because several factors affect the increase in students' learning implementation in class. At the initial meeting, students try to adapt to the model used so that students have more interaction at the next meeting. Presentation of interesting problems at each meeting will also affect student interest. The presentation of problems used in learning uses interactive multimedia, so students are more interested in participating in the learning process. The average result of the percentage of learning implementation by students obtained is $85.2 \%$ and includes perfect criteria $(75 \%$ Value 100\%) (Depdiknas, 2005).

Learning activities will form an understanding of a concept called a conception. Students' understanding of concepts can be grouped into three: knowing concepts, not learning concepts, and misconceptions (Hasan et al., 1999).

The misconception is one understanding of the concept that is not by the experts. One way to discover students' misconceptions is by using a diagnostic test. The use of diagnostic tests at the beginning and the end of learning can help teachers find misconceptions in the material to be studied (Irsanti et al., 2017)

The diagnostic test used for tracking misconceptions is in the form of multiple-choice equipped with CRI. This test was carried out two times, namely, through pretest and posttest, grouping students' conceptions based on the results of the pretest and posttest in the categories of Know Concept (KC), Don't Know Concept (DKC), and Misconceptions (MC) on each concept that represents the material Acid solution bases are presented in Table 4 . 
Table 4. Conception data of class XI IPA 2 students on acid-base solution material (pre-test)

\begin{tabular}{clccc}
\hline \multirow{2}{*}{ No } & \multicolumn{1}{c}{ Concept } & \multicolumn{3}{c}{ Percentage (\%) } \\
\cline { 3 - 5 } & & KC & DKC & MC \\
\hline 1 & Acid-Base Theories & 15.2 & 46.4 & 44.4 \\
2 & Acid-Base Properties & 13.7 & 48.5 & 31.8 \\
3 & Degree of Acidity (pH) or Degree of Ionization & 26.3 & 21.2 & 52.5 \\
4 & Acid-Base Indicator & 18.2 & 47.0 & 34.8 \\
\hline \multicolumn{2}{c}{ Average } & $\mathbf{1 9 . 8}$ & $\mathbf{3 9 . 3}$ & $\mathbf{4 2 . 9}$ \\
\hline
\end{tabular}

Based on the pretest data for class XI IPA 2 above, the average percentage of students who know the concept (KC), don't know the concept (DKC), and misconceptions (MC) are $19.8 \%, 39.3 \%$, and $42.9 \%$, respectively. More details can be seen in Figure 1.

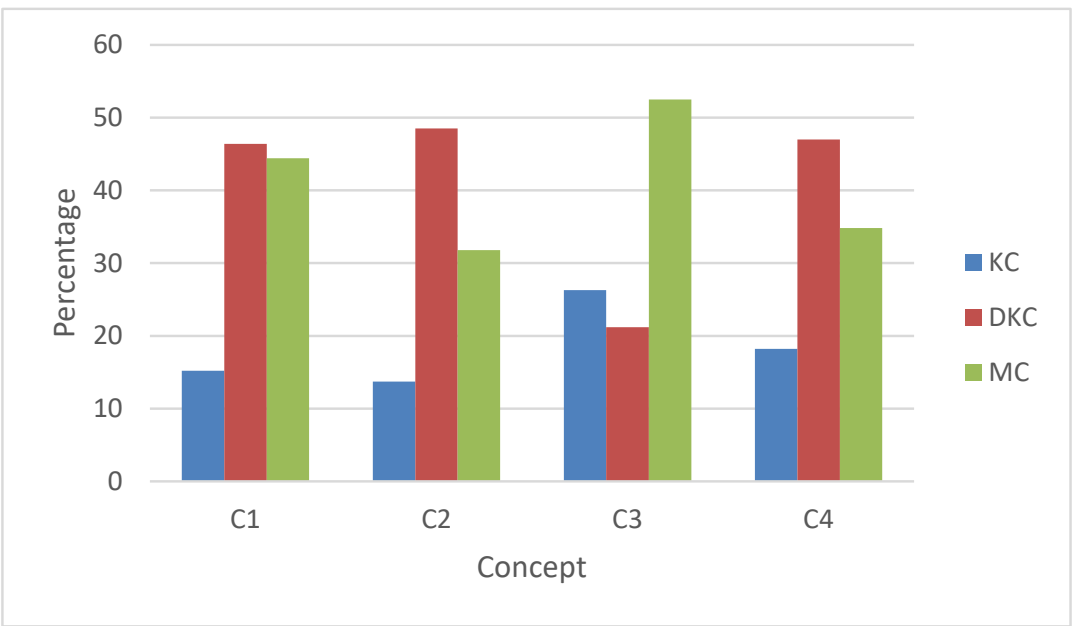

Figure 1. Percentage of class XI IPA 2 students who know the concept (KC), don't know the concept (DKC), and misconceptions (MC) in the pretest for acid-base solution material

Based on the data in Figure 1 it can be explained that (1) of the four concepts tested all caused students to experience misconceptions. (2) Most students, more than $(>40 \%)$, are in the misconception group, namely concepts number 1 and 3, while concepts 2 and 4 are less than $(<40 \%)$ students who experience misconceptions. The overall data is presented in Figure 2.

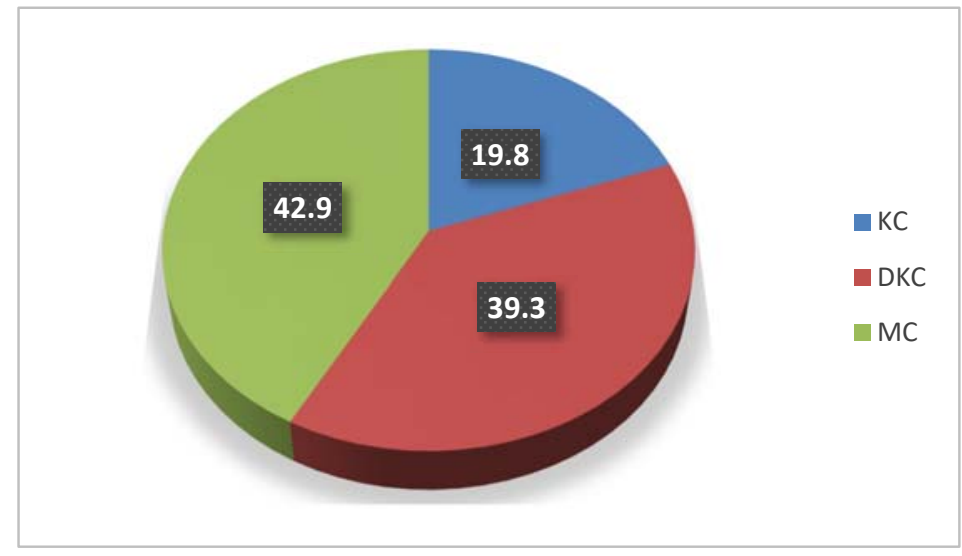

Figure 2. The average percentage of students in class XI IPA 2 who know the concept (KC), do not know the concept (DKC), and misconceptions (MC) in the pretest for acid-base solution material 
Based on the data in Figure 2 it can be obtained that the average value of the percentage of students' conceptions for Concept Know (KC), Don't Know Concept (DKC) and Misconception (MC) are $19.8 \%, 39.3 \%$, and 42 , respectively. These data explain that students who experience misconceptions on the pretest are still quite large. Misunderstandings can be seen from students' answers to the tests given and seen from the level of confidence or CRI associated with the solutions in each number of questions. Meanwhile, students who do not know the concept are bigger than students who know the idea. Identification of misconceptions in groups is used to determine the concept that is thought to have the most substantial misunderstanding from the four concepts tested. Identification is based on CRIB, CRIS, and Fb data for each test item representing the Acid-Base Solution concepts. CRIB, CRIS, and Fb data calculated from the pretest results are presented in Figure 3 .

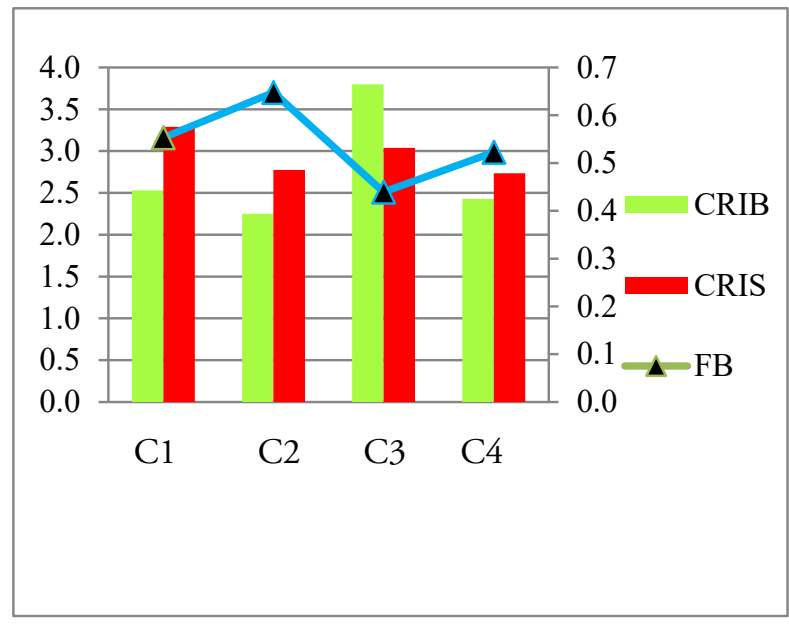

Figure 3. CRIB, CRIS, and Fb pretest of class XI IPA 2 students for acid-base solution material

Based on Figure 3, the CRIS and $\mathrm{Fb}$ values in each concept tested, some students have misconceptions. Misconceptions occur in all these concepts, and their impact is powerful. According to Hasan et al. (1999), if the CRIS value > 2.5 and
$\mathrm{Fb}<0.5$ are understood by students in a misconception and have a substantial impact, and the degree of influence of misconceptions is declared strong if the CRIS value is significant and the $\mathrm{Fb}$ value is small

Table 5. Conception data of class XI IPA 2 students on acid-base solution material (post-test)

\begin{tabular}{clrrr}
\hline \multirow{2}{*}{ No } & & \multicolumn{3}{c}{ Percentage (\%) } \\
\cline { 3 - 5 } & & 55.6 & 22.7 & 21.7 \\
\hline 1 & Acid-Base Theories & 51.5 & 33.3 & 15.2 \\
2 & Acid-Base Properties & 40.4 & 30.3 & 29.3 \\
3 & Degree of Acidity $(\mathrm{pH})$ or Degree of Ionization & 62.1 & 16.7 & 21.2 \\
4 & Acid-Base Indicator & 52.4 & 25.8 & 21.8 \\
\hline \multicolumn{2}{c}{ Average } & & &
\end{tabular}

Students experienced misconceptions in each concept tested on the Acid-Base Solution material based on the pretest results. Each student has a different form of misunderstanding on each idea; some students also have two forms of misconception on one existing concept.

For example, in concept 3 , namely the degree of acidity $(\mathrm{pH})$ or ionization, 21 out of 33 students who had misconceptions answered the question using the wrong concept, stating that the strength of an acid-base was seen from the $\mathrm{pH}$ list for a particular compound. At the same time, the actual concept is that the power of an acid-base is related to the ability of an acid or base to ionize in water, which is expressed by the values of $\mathrm{Ka}$ and $\mathrm{Kb}$. This shows that students' initial understanding of the concept is still not by the actual knowledge of the expert. Therefore, the learning process is carried out by applying a suitable model to reduce the misconceptions experienced by students. The learning process is carried out using the Problem Based Learning (PBL) model with the help of interactive multimedia. The PBL model is a learning model that fully involves students in problemsolving but is still under the teacher's guidance. This model is combined with interactive multimedia to make the presentation of problems in the learning process more enjoyable. 
After carrying out the learning process using the problem-based learning (PBL) model assisted by interactive multimedia, students were given a learning outcome test (posttest) at the end of the meeting. Student learning outcomes test in the form of multiple-choice questions accompanied by CRI, totaling 15 items that have been validated where the questions are the same questions at the pretest, to know the extent of students' misconceptions about the Problem Based Learning (PBL) model assisted by interactive multimedia on acid-base solutions.

Based on the pretest data for class XI IPA 2 in Table 5, the average percentage of students who know the concept (KC), do not know the concept (DKC), and misconceptions (MC) are 52.4\%, $25.8 \%$, and $21.8 \%$, respectively. More details can be seen in Figure 4.

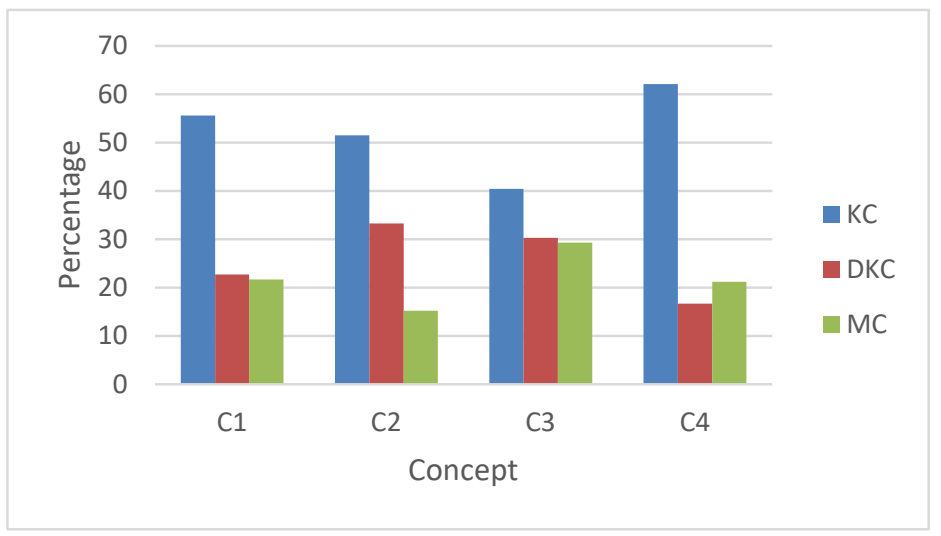

Figure 4. Percentage of students in class XI IPA 2 who know the concept (KC), do not know the concept (DKC), and misconceptions (MC) in the posttest for acid-base solution materi

Based on the data in Figure 4. it can be explained that (1) of the four concepts tested, all of them still cause students to experience misconceptions. (2) Concepts that are still responded to by misconceptions are more than (>20\%), namely concepts 1,3 , and 4. While concept two is responded to by misconceptions less than $(<20 \%)$. (3) Students' responses in general misconceptions about the concept of Acid-Base Solution material in Class XI IPA 2 have decreased but have not been eliminated. (2) Concepts that are still responded to with high misconceptions are above $20 \%$ in concepts 1,3 , and 4 (Acid-Base Theory, Degree of Acidity ( $\mathrm{pH}$ ), and Acid-Base Indicators)_overall presented in Figure 5.

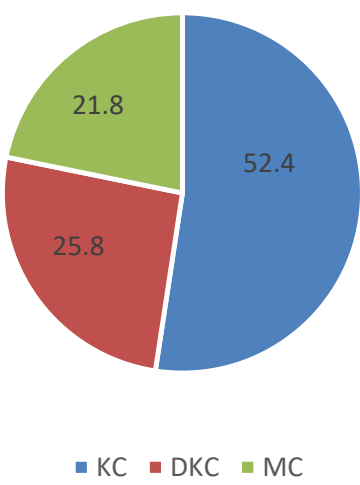

Figure 5. The average percentage of students in class XI IPA 2 who know the concept (KC), do not know the concept (DKC), and misconceptions (MC) in the posttest implementation for acid-base solution material.

Based on the data in Figure 5. it can be seen that the average value of the percentage of students' conceptions for Concept Know (KC), Don't Know Concept (DKC) and Misconception (MC) are
$52.4 \%, 25.8 \%$, and 21 , respectively. $8 \%$. From these data, it was explained that students who experienced misconceptions in the posttest were still quite large but experienced a decrease from the 
pretest. Misunderstandings can be seen from students' answers to the tests given and seen from the level of confidence or CRI associated with the solutions in each number of questions. Meanwhile, students who know the concept are bigger than students who do not understand the idea. Identification of misconceptions in groups is used to determine the concept that is thought to have the most vital misconception from the four concepts tested. Identification is based on CRIB, CRIS, and $\mathrm{Fb}$ data for each test item representing the Acid-Base Solution concepts. CRIB, CRIS, and Fb data calculated from the posttest results are presented in Figure 6.

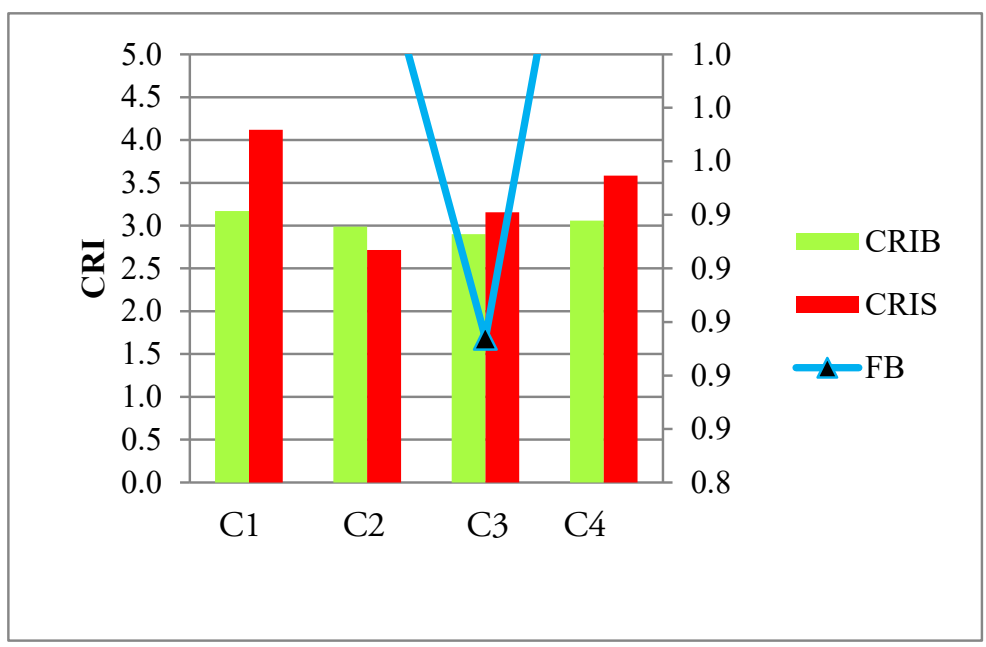

Figure 6. CRIB, CRIS, and Fb posttest for class XI IPA 2 students for acid-base solution material

Based on Figure 6 the CRIS and $\mathrm{Fb}$ values in each concept tested, some students had misconceptions. However, the misconceptions did not have a substantial impact. All ideas have a CRIS value > 2.5 , and $\mathrm{Fb}>0.5$ are understood by students misconceptions but do not have a considerable effect; this is following the theory put forward by (Hasan, 1999) which states that if the CRIS value is
$>2.5$ and $\mathrm{Fb}<$ students with misconceptions understand 0.5 , and the degree of impact of misconceptions is said to be vital if the CRIS value is significant and the $\mathrm{Fb}$ value is small.

Overall, the average percentage of students' misconceptions using the PBL model assisted by interactive multimedia on Acid-Base Solution material for class XI IPA 2 is presented in Table 6.

Table 6. The average percentage of students misconceptions in the pretest and posttest class XI IPA 2

\begin{tabular}{ccccc}
\hline \multirow{2}{*}{ No } & \multirow{2}{*}{ Concept } & \multicolumn{3}{c}{ Misconceptions (\%) } \\
\cline { 3 - 5 } & & Pretest & Posttest & Difference \\
\hline 1 & I & 44.4 & 21.7 & 22.7 \\
2 & II & 31.8 & 15.2 & 16.6 \\
3 & III & 52.5 & 29.3 & 23.2 \\
4 & IV & 34.8 & 21.2 & 13.6 \\
\hline & Average & 42.9 & 21.8 & 21.1 \\
\hline
\end{tabular}

Based on the pre-test and post-test results, the average percentage of students' misconceptions on the acid-base solution material using the Problem
Based Learning (PBL) model with interactive multimedia assistance is $42.9 \%$ and $21.8 \%$, presented in Table 7.

Table 7. Percentage of students' misconceptions in the pretest and posttest class XI IPA 2

\begin{tabular}{ccc}
\hline Pre-test $(\%)$ & Posttest $(\%)$ & Difference $(\%)$ \\
\hline 42.9 & 21.8 & 21.1 \\
\hline
\end{tabular}

Based on Table 7, it is found that the average percentage of misconceptions that occur is still too high or has not experienced a significant decline; this happens because of the different levels of students' abilities in working on questions, as well as limited student learning references so that the teacher still guides the development of each concept students.
The PBL model assisted by interactive multimedia is the main factor in decreasing misconceptions. This is because implementing learning is carried out in the most attractive way possible for each meeting. Students tend to be encouraged to continue to follow the learning process. This is evidenced by the average percentage of teacher and student activities of $87.9 \%$ and 
$85.2 \%$, respectively, which, according to (Depdiknas, 2005), are included in perfect criteria, namely at $75 \%$ Value $100 \%$.

\section{Conclusions}

Based on the research data analysis results, it can be concluded that: The average percentage of students' misconceptions in Problem Based Learning (PBL) learning assisted by interactive multimedia on Acid-Base Solution material, before and after the application, respectively, are $42.9 \%$ and $21.8 \%$. Thus, applying the PBL model can reduce students' misconceptions by $21.1 \%$.

\section{Acknowledgment}

The author would like to thank the principal of SMA Negeri 4 Palu, a chemistry subject teacher and students of class XI IPA 2 SMA Negeri 4 Palu for the 2018/2019 academic year, as well as all parties who helped the author in completing this research.

\section{References}

Afadil, \& Diah, A. W. M. (2018). Effectiveness of learning materials with science-philosophy oriented to reduce misconception of students on chemistry. Atlantis Press, 174(Ice 2017), 192-196.

Amrulloh, R., Yuliani, \& Isnawati. (2013). Kelayakan teoritis media pembelajaran multimedia interaktif materi mutasi untuk SMA. Jurnal BioEdu, 2(2), 134-136.

Astuti, F., Redjeki, T., \& Nurhayati, N. D. (2016). Identifikasi miskonsepsi dan penyebabnya pada siswa kelas XI MIA SMA Negeri 1 Sukoharjo pada materi pokok stoikiometri. Jurnal Pendidikan Kimia (JPK), 5(2), 10-17.

Depdiknas. (2005). Evaluasi pembelajaran. Jakarta: Direktorat Pendidikan Nasional.

Desnylasari, E., Mulyani, S., \& Mulyani, B. (2016). Pengaruh model pembelajaran project based learning dan problem based learning pada materi termokimia terhadap prestasi belajar siswa kelas XI SMA Negeri 1 Karanganyar tahun pelajaran 2015/2016. Jurnal Pendidikan Kimia, 5(1), 134-142.

Devi, A. A., Saputro, S., \& S, A. N. C. (2014). Pengembangan multimedia interaktif elektrolit untuk pembelajaran kimia siswa SMK kelas XI jurusan pertanian tahun pelajaran 2013/2014. Jurnal Pendidikan Kimia (JPK), 3(2), 45-50.

Gabel, D. (1999). Improving teaching and learning through chemistry education research a look to the future. Journal of Chemical Education, $76(4), 548-554$.
Hasan, S., Bagayoko, D., \& Kelley, E. L. (1999). Misconceptions and the certainty of response index (CRI). Journal of Physics Education, 34(5), 294-299.

Hastuti, W. J., Suyono, \& Poedjiastoeti, S. (2014). Reduksi miskonsepsi siswa pada konsep reaksi redoks melalui model ECIRR. Jurnal Penelitian Pendidikan Kimia, 1(1), 78-86.

Irsanti, R., Khaldun, I., \& Hanum, L. (2017). Identifikasi miskonsepsi siswa menggunakan four-tier diagnostic test pada materi larutan elektrolit dan larutan non elektrolit di kelas X SMA Islam Al-falah Kabupaten Aceh Besar abstrak pendahuluan metode penelitian. Jurnal Ilmiah Mahasiswa Pendidikan Kimia (JIMPK), 2(3), 230-237.

Medina, P. (2017). Analisis miskonsepsi siswa kelas $X$ pada materi larutan elektrolit dan non elektrolit serta reaksi oksidasi dan reduksi dalam pembelajaran kimia di SMAN 10 Kota Padang. Journal of Residu, 1(1), 73-84.

Nuha, W.U., \& Sukarmin. (2013). Software development for detecting chemical misconceptions. Journal of Chemical Education, 2(3), 85-89.

Nurhayati, L., Martini, K. S., \& Redjeki, T. (2013). Peningkatan kreativitas dan prestasi belajar pada materi minyak bumi melalui penerapan model pembelajaran problem based learning (PBL) dengan media crossword. Jurnal Pendidikan Kimia (JPK), 2(4), 151-158.

Rosidah, R., Wasonowati, T., Redjeki, T., \& Dwi, R. (2014). Penerapan model problem based learning (PBL) pada pembelajaran hukumhukum dasar kimia ditinjau dari aktivitas dan hasil belajar siswa kelas X IPA SMA Negeri 2 Surakarta tahun pelajaran 2013/2014. Jurnal Pendidikan Kimia, 3(3), 66-75.

Sugiyono. (2015). Metode penelitian pendidikan (pendekatan kuantitatif, kualitatif, dan R\&D). Bandung: CV. Alfabeta.

Yang, E., Greenbowe, T.J., \& Andre, T. (2004). Teaching with technology the effective use of an interactive software program to reduce students' misconceptions about batteries. Journal of Chemical Education, 81(4), 587-595.

Yunitasari, W., Susilowati, E., \& Nurhayati, D. (2013). Pembelajaran direct instruction disertai hierarki konsep untuk mereduksi miskonsepsi siswa pada materi larutan penyangga kelas XI semester genap SMA Negeri 2 Sragen tahun ajaran 2012/2013. Jurnal Pendidikan Kimia (JPK), 2(3), 182-190. 